\title{
Buddhist Literature: A Cosmopolitan Philosophy
}

\author{
Pradeep Kumar Giri, $\mathrm{PhD}^{*}$
}

\begin{abstract}
This article argues that literatureof Buddha's philosophy has cosmopolitan nature. Buddhists do not believe in a personal creator God. In this sense, Buddhism is more than a religion; it is not centered only on the relationship between humans and a high God. Buddhism is a philosophical tradition that believes and centers on personal spiritual development. It is a humanistic way of life which can be understood as motivated to lead a moral life; it is also conscious of one's thoughts and actions as well as in developing wisdom and compassion. Both Buddhism and cosmopolitanism assert the dignity of every human being; these ideals aim at improving the condition of life. Philanthropy, empathy, and compassion can be considered as synonyms for Buddhism and cosmopolitanism. Service to fellow human beings is at the center for a cosmopolitan. When humans ascend the material concerns like pleasure and material desire, they are free to fulfill responsibilities to fellow human beings so that they can go up and beyond the close family members to all human beings, which is the philosophy of both Buddhism and cosmopolitanism. In both the Buddhist and cosmopolitan philosophy there is basic consideration of humanity. Buddhist social thought offers something to cosmopolitan ethics that cosmopolitanism's desire to enhance 'human interconnectedness' is truly helpful to minimize the human sufferings. In this article, my goal is to explore and show Buddhism as a cosmopolitan philosophy.
\end{abstract}

Key words: Buddhism, Cosmopolitanism, humanistic way, wisdom, compassion,

\section{Commonality in Cosmopolitan and Buddhist Philosophy}

On the basis of the commonality and mutual inclusivity in the notions of cosmopolitanism and Buddhism they can march together in the issue of the development of humanity. In both the Buddhism and cosmopolitanism there is 'basic considerations of humanity' (Linklater 2007: 135). Linklater's argument is that common humanity can be the basis of harmonious unity which is treated with deep skepticism in the social sciences today notwithstanding attempts to rescue the broader ideal (Wilde 2004: 162).

*Dr. Giri has done PhD from Tribhuvan University and has been working as the Associate Professor of English at Trichandra Campus, TU, Nepal. 
Buddhist thought accepts the notion that suffering is common and omnipresent; it considers social collectivities that give emphasis to deep bonds of accountability and affinity at all levels of both the human and on-human world. There is suffering in human. The strength of its suffering solidarity complex rests on a fundamental explanation of the self. Buddhist social thought suggests something to cosmopolitan ethics that cosmopolitanism's desire to enhance 'human interconnectedness (Linklater 2009 ) is really helpful to minimize the sufferings that humans face.

Altruism, empathy, and compassion are synonyms for Buddhism and humanism. Whether we call it-- enlightenment or -- the conviction that humanity has the ability to progress toward its highest ideals, and we are, indeed, on common ground.

Buddhism is a philosophical movement that follows the teachings of Siddhartha Gautama. The Buddha's philosophy of life teaches the right way to live. The Buddha's teachings aimed at eliminating ignorance by understanding and seeing dependent origination and eliminating desire, and thus attain nirvana. Compassion becomes real when we recognize our shared humanity. Humanism is a philosophy inspired by art and informed by science; it is motivated by compassion. It supports the expansion of individual liberty and opportunity; it also asserts the dignity of each human being. It gives importance and advocates for human rights and social justice. Humanism, thus, derives the goals of life from human need and interest rather than from theological or ideological notions, and stresses that humanity must take responsibility for its own destiny. It is understood that the 'sticky web of universalism' (Santoro 2011) mixed up in arguments for humanity produces both exclusion and integration.

\section{A Critical Reflection on the Buddha and the Buddhist Philosophy}

Siddhartha Gautama, after seven days and nights of meditation he attained enlightenment and became known as "the Buddha," --enlightened one. He taught monks, disciples, and general public of various places until his peaceful death at the age of eighty years in Kushinagar- northern part of present-day India. After the Buddha gained the insight, he started teaching his philosophy and gained a large number of followers. Then he went on a journey of teaching others the path that would liberate them from the cycle of life and death. Richard H. Robinson and others say:

The Four Noble Truths lie at the essence of that liberating insight. These truths are best understood not as the content of a belief, but as phenomenological categories, a framework for viewing and classifying the processes of experience as they are directly present to the awareness.... avoids many of the complicated issues that come with the notion of self: for example, the need to identify what it is, to confirm or deny its existence, and the imperative to maximize its well-being either by exploiting the "other" or by swallowing the 
"other" into the self by equating the latter with the cosmos as a whole. (The

Buddhist Religion: A Historical Introduction 35)

The Buddhist philosophy does not believe in the dichotomy of self and other. The Buddha stresses to consider the cosmos as a whole rather than having the parochial conviction of me and mine.

Buddhism is a practice for the spiritual attainment and liberation of the individual; it also emphasizes the need to practice for self-actualization and to liberate all beings from suffering. In this philosophy, Dharma is known as the Buddha's lessons and teachings pointed toward the true nature of the universe. He gave his first sermon on the outskirts of the city of Varanasi (India) at a deer park called Sarnath. This first sermon presents an overview of suffering and the way out of suffering.

Buddhism believes in 'samsara' - meaning the repetitive cycle of birth and death. The process of rebirth refers to a cycle of lives with many potential forms. Within this cycle there is no permanent entity as a soul. Therefore, rebirth is continuous and is governed by the laws of 'karma'. All living beings lay open to 'samsara' until they attain 'nirvana' - spiritual enlightenment. Nirvana means the removal of suffering and 'samsara'. The awakening or enlightenment that goes together with the reaching of 'nirvana' is called 'Bodhi'. In Buddhist tradition a Buddha is an enlightened one and is free from suffering and 'samsara'. By following the Buddhist philosophy, emancipation can be achieved. 'Karma' is the belief that our past actions affect us; and our present actions will affect us in the future. Buddhists try to avoid bad 'karma' and nurture good as they believe in the cycle of birth and death.

\section{Buddhism: a Philosophy to Become a Virtuous Citizen}

The Buddha- a son of a king - emphasized that he was not a god but was simply a human being who was "fully awake," attentive, and aware of the here and now. As the Buddha is not a god he is not worshipped by Buddhists as a god or embodiment of God. To get ideas on the Buddha and Buddhism the following extract is worthy:

Buddhism -as a term to denote the vast array of social and cultural phenomena that have clustered in the course of time around the teachings of a figure called the Buddha, the Awakened One. . . . Previously, the terms they used to refer to their religion were much more limited in scope: the Dharma, the Buddha's message, or the Buddha's way. In other words, they conceived of their religion simply as the teaching of the Buddha, what the Buddha himself called DharmaVinaya (Doctrine and Discipline). Whereas Dharma-Vinaya is meant to be prescriptive, advocating a way of life and practice, Buddhism is descriptive in that it simply denotes the actions of people who follow a vision of Dharma- 
Vinaya without suggesting that the reader accept that vision or follow it, too.

(The Buddhist Religion: A Historical Introduction, 1997:1)

Buddhism is not just a religion, but it is rather related to social and cultural phenomenon and advocates a way of life and practice.

Buddhism does not have one single sacred book like the Bible; there are many sacred texts called sutras (the Buddha's teachings) which are the spoken words of the Buddha. There are thousands of sutras. The Buddha's teachings were orally transmitted through the oral tradition until they were recorded after his death. The Tripitaka (literally "Three Baskets") is a large collection of the Buddha's teachings. Tripitaka- the central sacred text of Buddhism - teaches Buddhist philosophy of life as meditation and chanting that are the forms of prayer. There is no one holy day in Buddhism, every day is sacred. Meditation is of great significance in the Buddhist philosophy as viewed in the quotation below:

As we have noted, in the third watch of the night Gautama discovered the causes and cure for bondage to samsara. The variant accounts agree that the basis of this discovery was the realization of pratitya-samutpada (dependent co-arising), which came to be regarded as the heart of the Buddha's Awakening. A Pali Sutta (M.28) says, and "Whoever sees dependent co-arising sees the Dharma." "Dharma" here has three levels of meaning: doctrine, practice, and nirvana (attainment). On the first two levels, dependent co-arising and Dharma came to be viewed as equivalent. . . On the level of practice, dependent co-arising functioned as the map for unraveling the causal process; through its complexity it also became the riddle that the practitioner tried to comprehend through meditation. (The Buddhist Religion: A Historical Introduction1997:23)

As prince Shiddhartha had left the palace to find the way out of the bondage to 'samsara', he discovered the causes and cure for it. 'Dharma', as mentioned in Pali Sutta, has three levels: doctrine, practice, and nirvana (attainment).

As both cosmopolitanism and the Buddhism give importance to humanism, a brief discussion on humanistic Buddhism becomes useful. To understand the potentials of a Humanistic Buddhism we have to understand the basic notions of these two loaded ideals. There is a great deal of commonality in Buddhism and humanism. Both of these ideals do not believe in a creator God; they emphases on social justice and reason. The common values which various schools of Buddhism associate with humanism center on empathy and the inherent dignity of all people. Compassion and the values of encouraging humanistic action like the deep respect for human rights are mutually inclusive in both of them. Humanism can and should be a way of life for everyone everywhere and every day. 
A person with the humanistic attitude in the true sense believes in enhancing human welfare. Minimizing suffering, making fair decisions, and enhancing human freedom and dignity are other goals for him/her. Humanist ethics are based on compassion, reason, responsibility, and belief in the value and self-esteem of human beings. The efforts to avoid the barriers which the less fortunate is another goal of a humanist. Faith in the kindness of human being's devotion for the promotion of human happiness paves way to reach the summit of humanist ethics. Buddhist view of traditional concept does not have faith in the notion of a creator god, it maintains belief in the divine nature of life and the holiness of all things including animals, plants, mountains, and so on. Self-respect and goodwill toward other persons incorporated in the Noble Eightfold Path are the Sutras which outlook the altruistic points of view ultimately focusing on humanism.

In Humanism as The Next Step (1998), Lloyd and Mary Morain present a general idea of the history and principles of modern humanism. Concentrating on caring for the living, working for the benefit of others, compassion and altruism are mainly concerned with issues of the world than on how to leave the world behind. It, therefore, is concerned with doing good to others rather than oneself. Furthermore, it is a fundamentally optimistic belief in the dignity of humans and their ability to transform themselves in a positive and altruistic manner.

Humanism, Humanistic Buddhism, and Secular Buddhism are mutually inclusive to each other. Humanism-based Buddhism rather than entirely faith-based is getting popularity and in practice today. Various Buddhists today are doubtful of faith-based claims and have the conclusion that they do not believe in gods, gurus or the supernatural, but they still practice some Buddhist techniques and traditions mostly as instructions of the philosophy of life. The Buddhists who advocate only those beliefs and practices that are set by reason and science are secularists. They are more humanists than religious as they do their utmost to be ethical, sympathetic and altruistic. In core, they who meditate and honor Buddhism's secular contributions are humanists. For that reason, they call themselves secular and humanistic Buddhists.

\section{A Critical Overview on Cosmopolitanism}

Cosmopolitanism is the ideology that gives an insight that all human beings belong to a single community based on a shared morality. It hints that all human beings, regardless of their citizenship, religion, political affiliation and other forms of boundaries, belong to a single community. This ideal considers the individual human being as the basic unit. The roots of cosmopolitanism are in the thought of the Ancient Greek Philosopher Diogenes, who lived around the time of Plato. In ancient Greece a "kosmopolítes" was a "citizen of the world." The term came to indicate someone who 
considered the entire humankind as more meaningful than his or her own city, group, region, religion, or nation. Ulrich Beck writes in New Statesman:

The key idea for cosmopolitan manifesto is that there is a new dialectic of global and local questions, which do not fit into national politics. These questions are already part of the political agenda-in the localities and regions, in governments and public spheres both national and international. But only in a transnational framework can they be properly posed, debated and resolved. For this there has to be a reinvention of politics, a founding and grounding of the new political subject: that is- cosmopolitan parties. (29)

Cosmopolitanism does not believe in certain community or group of any kind having special ties and obligations to its members, rather it believes in equal treatment from the point of view of humanity which lies at the core of this theory. Writers like Salman Rushdie are engaged in "thinking and acting beyond the local." They have imagined collective rights and obligations in retreat from the nation. Talking about Goethe's concept on cosmopolitanism, Hans Kohn says that Goethe would agree, "The fatherland of the man who thinks without prejudice, who can rise above his time, is nowhere and everywhere" (qtd. in Kohn 414).

\section{Cosmopolitan Conception in Buddhist Philosophy}

Notions of cosmopolitanism richly passed through the writings of the major Enlightenment thinkers. They viewed all races and all continents with the same human interest and concern. Montesquieu (1689-1755) wrote that if he knew something useful to his fatherland, which was prejudicial to Europe or something, which were useful to Europe and prejudicial to humankind, he would consider it a crime.

Compassion and help for the suffering of others is a defining characteristic of the original teachings and, a virtue in Buddhism. It is much-loved across the different traditions as belonging to a family. On intensification of the reality of the emptiness of self and of our own suffering, we draw on these essential qualities to respond with compassion. In this sense, compassion for others is not separate from compassion for ourselves. For Cho (2000: 80) selflessness provides the basis for a Buddhist theory of a rational social justice, it is the doorway from ontology to phenomenology. Altruism becomes a rational response to suffering in the world (Harris 2011). Thus, compassion is not directly related with the idea of an emotionality or with a subjective feeling but becomes a relationship quality (Her shock 2006) that arises in a world of radical ontological rationality. For Buddhist social theorists, compassion is, therefore located alongside suffering in a socio-existential account of the human condition (Jones 2003: 212-3). 
Sanchez-Flores (2010) initiates for a cosmopolitanism that expands the self to overcome cosmopolitanism's negative identification with the project of modernity. Delanty reworks of critical theory that argues that cosmopolitanism arises with the transformation of collectivities in the light of 'the encounter with the Other' (2009: 253), occurring equally indiasporic exchanges and creolisation as in the process of globalization today. The refusal of the self is ontologically separate and distinct. Its viscerality is captured by a Thai activist, cited in Harris (2001: 66) : . . is to explore what Buddhist thought can tell us about suffering and solidarity following Linklater's founding argumentsfor cosmopolitan solidarity. If the point of solidarity between strangers rests most immediately on common vulnerabilities to mental and physical suffering, in order to create an overlapping agreement about inhumane behavior (Linklater 2011: 1-28). Zestern thought principally imagines suffering as standing against or as opposed to our humanity (Wilkinson 2005: 1) exemplified by Fineman's (2008) account of suffering and helplessness as a split to the normally functioning, autonomous person.

Cosmopolitan thought signals towards a reconception of the 'self' which shifts its boundedness in sociality towards a hold of the 'society of strangers' (Ossewaarde, 2007). Buddhist thought offers a way of conceiving a cosmopolitan self in which all inscriptions of forms of identity like cultural, ethnic, national are empty and impermanent to begin with. For Buddhism, appreciation of the emptiness of that 'self' is both the source of our liberation and of solidarity. A Buddhist social theory exemplifies normative cosmopolitanism and offers, following Linklater, one 'structure of consciousness' (2011: 266) that is essentially cosmopolitan.

\section{Conclusion}

In the teachings of Buddhist philosophy what we find is that the flesh could and should be transcended because it was thought to be of lesser importance to perfect reason and virtuous living. Our most important goal in life is to become a good worldcitizen. Buddhist philosophy aims at achieving a pureness in soul which helps become a virtuous citizen; it also asserts that happiness is attained by personal development. This is possible to achieve by rejecting the desires of the flesh through reason. Cosmopolitan philosophy believes that humans are responsible for not only himself/herself but others also who are part of the universal whole. Therefore, in ancient Greece a "kosmopolíte" was considered as a "citizen of the world." The term "kosmopolíte" came to indicate someone who considered the entire humankind as more meaningful than his or her own country, city, group, region, religion, or nation. In this article endeavor is made to prove that both in the Buddhism and Cosmopolitanism there is basic consideration and affinity in the issue of humanity. 


\section{References}

Beck, Ulrich (1998). "The Cosmopolitan Manifesto." New Statesman, 29.

Cho, S. (2000). “ "Selflessness": Towards a Buddhist Vision of Social Justice'. Journal of Buddhist Ethics, 7, pp. 76-85.

Delanty, G. (2009). The Cosmopolitan Imagination. Cambridge University Press.

Fineman, M. (2008). 'The Vulnerable Subject: Anchoring Equality in the Human Condition'. Yale Journal of Law and Feminism, 20(1), pp. 1-23.Harris, E. (2001).What Buddhists Believe. One World.

Harris, S. (2011). 'Does $A n^{-}$atman Rationally Entail Altruism? On Bodhicary' avatara 8, 101-103', Journal of Buddhist Ethics, 18, pp. 93-123. Hershock, P. (2006).Buddhism in the Public Sphere. Oxford Centre for Buddhist Studies. Routledge.

Jones, K. (2003).The New Social Face of Buddhism: A Call to Action. Wisdom Books. Kohn, Hans (1944). The Idea of Nationalism: A Study in Its Origins and Background. Macmillan.

Linklater, A. (2007). 'Towards a Sociology of Global Morals with an "Emancipatory Intent." ' in N. Rengger and B. Thirkell-White (eds), Critical International Relations Theory after 25 Years, Cambridge University Press. - - (2009). 'Human Interconnectedness', International Relations, 23, pp.481-97. - - (2011). The Problem of Harm in World Politics, Cambridge University Press. Lloyd and Mary Morain (1998). Humanism as the Next Step. The Humanist Press, revised edition.

Ossewaarde, M. (2007). 'Cosmopolitanism and the Society of Strangers', Current Sociology, 55(3), pp. 367-88.Richard H. Robinson, Willard L. Johnson, and Sandra A. Wawrytko (ends),(1997).TheBuddhist Religion: A Historical Introduction, an International Thomson Publishing Company. Fourth Edition. Santoro, D. A. (2011). 'Review of Sharon Todd, Toward an Imperfect Education: Facing Humanity, Rethinking Cosmopolitanism.' Studies in Philosophy and Education, 30, pp.303-10.Sanchez-Flores, M. J. (2010).Cosmopolitan Liberalism: Expanding the Boundaries of the Individual. Palgrave Macmillan.

Wilde, L. (2004). 'A "Radical Humanist" Approach to the Concept of Solidarity.' Political Studies, 52, pp. 162-78. 